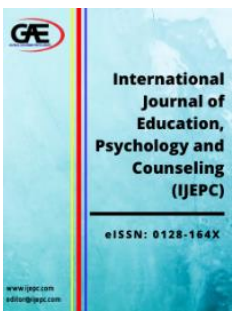

\author{
INTERNATIONAL JOURNAL OF \\ EDUCATION, PSYCHOLOGY \\ AND COUNSELLING \\ (IJEPC) \\ www.ijepc.com
}

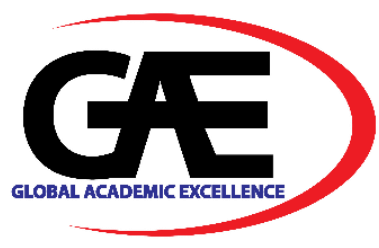

\title{
INTEGRATION OF THE ORGANIZATIONAL CULTURE AND HR PRACTICES OF THE SVD EDUCATIONAL INSTITUTIONS IN THE PHILIPPINES TOWARDS A MODEL OF INSTITUTIONALIZED HR POLICY:A LITERATURE REVIEW
}

\author{
Renato A. Tampol ${ }^{1 *}$, Hector M. Aguiling ${ }^{2}$ \\ 1 The Graduate School, University of Santo Tomas, Manila, Philippines \\ Email: natoytampol@gmail.com \\ 2 The Graduate School, University of Santo Tomas, Manila, Philippines \\ Email: hmaguling@yahoo.com \\ Corresponding Author
}

\section{Article Info:}

Received date: 27.11 .2020

Revised date: 24.12 .2020

Accepted date: 28.12 .2020

Published date: 31.12 .2020

To cite this document:

Tampol, R. A., \& Aguiling, H. M. (2020). Integration of The Organizational Culture and HR Practices of The SVD Educational Institutions in The Philippines Towards A Model of Institutionalized HR Policy: A Literature Review. International Journal of Education, Psychology and Counseling, 5 (37), 379-385.

DOI: $10.35631 /$ IJEPC.5370030.

This work is licensed under $\underline{\text { CC BY } 4.0}$

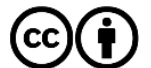

Abstract:

Human Resource (HR) policy is not a one-size-fits-all approach. Underpinnings and reasons for the development of HR policy may be parallel for most organizations, regardless of type and nature, but pertinent factors considered for such development may vary. The most common yet influential amongst the factors is the culture of the organization. Organizational culture is one of the most researched topics in organizational studies. It had been used as a construct in various settings, even in the education landscape. Previous studies show that organizational culture impacts the HR practices and policies of organizations. However, the literature is silent on its application in Catholic educational institutions' HR practices and policies in the Philippines. This study used literature review as its method to integrate organizational culture and HR practices toward institutionalizing their HR policies. Society of Divine Word (SVD) educational institutions within the Philippines A standard HR Policy is aimed to be used across all SVD schools in the Philippines.

Keywords:

HR Policies, HR Practices, Organizational Culture, SVD, Philippines 


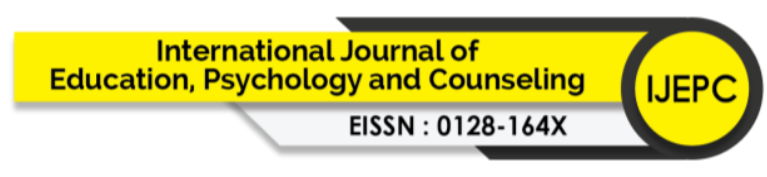

Volume 5 Issue 37 (December 2020) PP. 379-385

DOI 10.35631/IJEPC.5370030

\section{Introduction}

Human Resource (HR) policy is a principle or rule of conduct which govern the organization's relationship with its people. It ensures consistency in action. However, HR policy is not a onesize-fits-all approach. Underpinnings and reasons for the development of HR policy may be parallel for most organizations, regardless of type and nature, but pertinent factors considered for such development may vary. One of the most common yet influential amongst the factors is the culture of the organization.

Organizational culture is defined in numerous ways. For instance, Schein and Schein (2017) described organizational culture as "abstract" but has powerful effect on the behavior of the members of the organization. Organizational culture as a "link or bond" between the organization and its members. However, the most cited definition of culture in organizational research is "a set of norms, attitudes, values and behavior patterns that form the core identity of an organization or operating unit" (Denison, 1984, cited in Laforet, 2016, p.382; Mujib, 2017, p.1).

The culture of organization is mirrored by some manifestations or identities that set the organization apart from others. Scholars and researchers often labelled these individualities as the "organizational identity". Organizational identity is the "central, distinctive, and enduring characteristics of an organization" (Mujib, 2017, p.1). It is perceived to be the "essence" of the organization and has two constructs: culture and image. Organizational culture reflects the internal focus - "I" ("who am I?") which is shaped by the organization's members. Organizational image, on the other hand, is the external focus - "me" ("how others see us?") which is shaped by organization's members' interactions with key external shareholders (Mujib, 2017).

This research focused on how the SVD educational institutions can integrate organizational culture and their human resources activities or practices toward institutionalizing the human resource policies. A standard HR policy is aimed to be used across all SVD schools in the Philippines. Institutionalizing human resource policies, on this research's belief, can help the organization in aligning its strategies and decision-making with its cultural ideals to be able to achieve its visions and objectives.

\section{Literature Review}

\section{SVD Educational Institutions in the Philippines}

The crisis that besieged the Catholic Church in the Philippines during the twentieth century due to the departure of many Spanish missionaries and lack of Filipino clergy paved the way for the coming of the SVD missionaries who were tasked to administer parishes and parochial schools. These apostolates ushered a shift of missionary thrust of the Society to commit itself to school ministry. Soon thereafter, they were requested by some Bishops to administer or establish schools that would later become the Divine Word Educational Association (DWEA) (Layugan, 2012).

The Society of the Divine Word in the Philippines at present is into varied ministries already namely: parishes, seminaries, education, media and other special apostolates. The education ministry which is the focus of this study anchored its organizational culture on the core values of the organization, the DWEA of which all schools are members. These core values are to be 


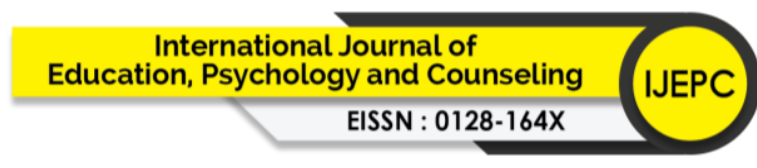

Volume 5 Issue 37 (December 2020) PP. 379-385

DOI 10.35631/IJEPC.5370030

integrated with the schools HR practices in order to come up with a standard Policy applicable to all.

\section{Integrity}

The SVD Philippines Educational Institutions are rooted in six (6) core values. The first value is integrity. A Christian's command to integrity is not to be compromised. It is a command to both talk and walk in the way of Jesus. This calls us to walk in the path of Christ, and to steer clear of hypocrisy (Hamm, 2013). It is a life marked by love, compassion, mercy, justice, and honoring God's call above everything else. It's the life spoken of Peter: "They must turn from evil and do good; they must seek peace and pursue it. For the eyes of the Lord are on the righteous and his ears are attentive to their prayer, but the face of the Lord is against those who do evil" (3:10-12).

This attitude of employees in the organization commands ethical considerations in its practices. Ethical considerations could mean that there is an ethical climate that strengthens employees support, identification and commitment to the organization (Zagenczyk, Purvis, Cruz, Thoroughgood \& Sawyer, 2020).

\section{Commitment}

Commitment refers to one's faithfulness to a certain goal that brings it to fulfilment (Bulmash, 2016). There are factors that contribute to the employee's commitment to the organization. In school setting, commitment of teachers to the organization comes from the administration's adherence to the principle of the so-called strong "HRM system" where there is an open communication, policies are consistently implemented, employees are consulted and they reached a consensus favorable to all (Waeyenberg, Peccei \& Decramer, 2020).

Organizational commitment is very often connected to professional commitment. These two have a mediating effect on the decision of the professional employees to stay in the organization or not (Valeau, Paille, Dubrulle \& Guenin, 2019).

The HRM policies and practices of the organization should be socially responsible catering to the needs of the employees. It should draw out the best in them to contribute to the welfare of the organization (Shen \& Zhu, 2011). It points to something important even outside the organization. This inspires employees to live a life worthy of being a member of the organization which they strongly commit themselves because they could relate to its goals and aspirations.

Aside from strong CSR that commands commitment to the organization, ethical climate also strengthens good relationship that inspires employees to identify, support and build a stronger commitment with the organization (Zagenczyk, Purvis, Cruz, Thoroughgood \& Sawyer, 2020). Ethical practices are not to be compromised at all times in the DWEA member schools.

\section{Evangelization}

The beginning of evangelization dates back to the time of Jesus who commanded His disciples to preach the Gospel to all people. The same command echoes until today through the Church He founded. The Church is commissioned by the Lord to continue the mission left by His disciples. And there are many ways to do mission today. They are the parishes seminaries, schools and special apostolates like media, social media and others. They existed in the name 


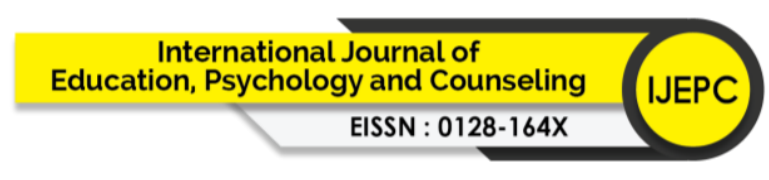

Volume 5 Issue 37 (December 2020) PP. 379-385

DOI 10.35631/IJEPC.5370030

of propagating the faith. In the context of this paper, the schools are instruments of the Church to do evangelization.

Schools have students from various faiths and Christian denominations. As it evangelizes, it respects others faith and culture (Presmanes, 2012). The Church has various relationships with culture. At times it blends with cultures that are not hostile to the faith but challenges cultures that are contrary to gospel values (Carey, 2011). A new approach has been introduced to preserve the identity of the schools through its core values and at the same time reaching out to those in need of evangelization and re-evangelization.

\section{Leadership}

Effective leaders in the Society of the Divine Word (SVD) must play the three (3) important roles: animation, coordination and administration. Animation is to usher the community to the fulfilment of its vision, mission and goals. Coordination means to delegate and coordinate responsibilities according to one's talents and skills. And administration is to be a faithful and prudent steward who acted in good faith even in the absence of his master.

Hence, leadership in the SVD is the commitment to serve with the attitude of solidarity, love and respect towards others (IDW Nr 6, 2006; IDW Nr 11, 2012). It is servant leadership rooted in Jesus the Divine Word made flesh "who came to serve and not to be served."

\section{Excellence}

Excellence is a core value common to all organizations. The DWEA is guiding its member schools in their goals and aspirations to excel in everything they do. To excel means to give their best as administrators, faculty, staff and students. It is not only to excel in one aspect of a person's life whether as a student or a teacher but to be outstanding beyond expectation. As an organization it is to give joy to stakeholders that creates commitment, allegiance and impression of lasting satisfaction, to serve to the delight of the frontline stakeholders in the context of the academe, the students, faculty and employees that strengthens loyalty and build long-term relationship (Asif \& Gouthier, 2013).

In another context especially in business, excellence is sought after so as to come up with an optimal job performance, and personal and professional growth at work are needed to focus on one direction to produce excellent job (Jaeger, 2017).

\section{Corporate Social Responsibility}

Corporate social responsibility (CSR) is where the organization expresses special concerns on its stakeholders internal and external. This helps the organization promote goodwill that inspires stakeholders to be supportive of its goals and aspirations. HRM practices help promote CSR development in the organization. It supports the internal implementation of its operation and strategy.

In relation to external CSR, roles of the experts, change agents and employee champion played a vital role in its development and implementation (Sarvaiya, Arrowsmith \& Eweje, 2019). Though such result of partnership between HRM and CSR vary depending on the organization. 


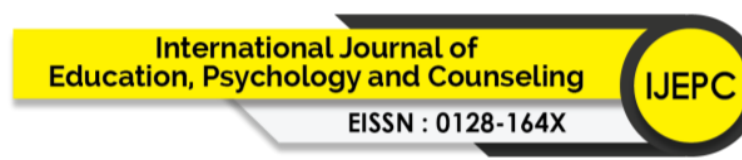

Volume 5 Issue 37 (December 2020) PP. 379-385

DOI 10.35631/IJEPC.5370030

In the context of the educational institutions, it is the Community Extension Services (CES) where the organization exercises its regular service to stakeholders. They are encouraged to create a sustainable program that could have a long-term effect to its recipients.

\section{Theoretical Framework}

This study focused on the integration of the organizational culture and the HR practices of the SVD institutions towards the development of a model institutional policy. The models used by (Alfante et.al., 2015), together with the Nadlers' HRsM classification model, will be helpful in explaining the process of integration of the organizational culture and HR practices.

\section{SVD Educational Institutions Organizational Culture}

Coleman (2013) in proposing a great corporate culture states that "A company's values are the core of its culture". In this particular study, the values that were placed under scrutiny was that which represented the SVD Educational institutions values which are the following: Integrity, Excellence, Commitment, Evangelization, Leadership and Social Responsibility. Coleman further explains that "values are of little importance unless they are enshrined in a company's practices".

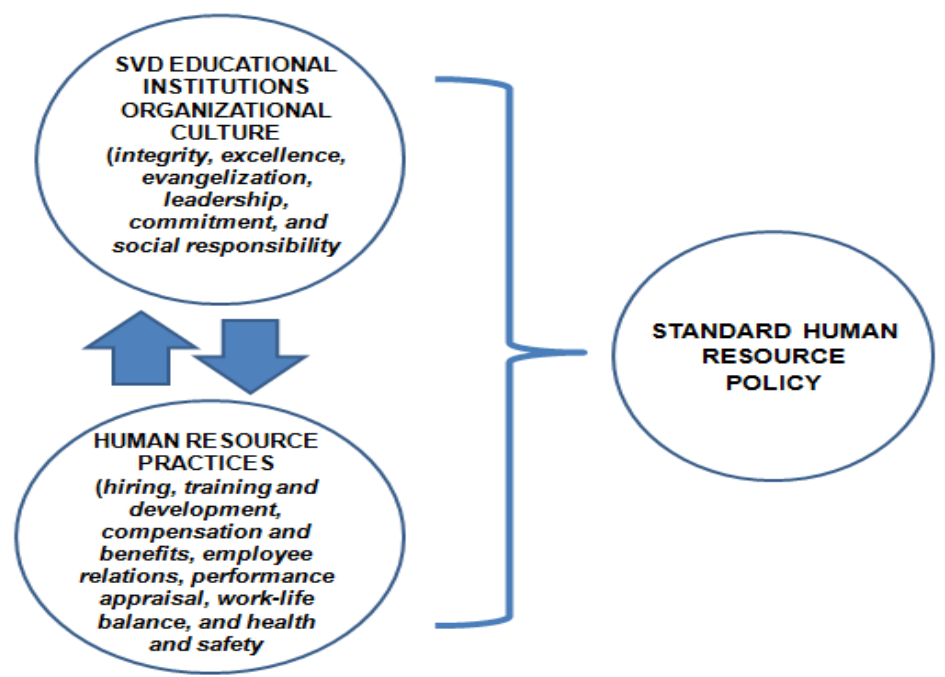

Figure 1. Schematic Diagram of the Integration of SVD Educational Institutions Organizational Culture and Human Resource Practices towards the proposed Standard HR Policy.

The schematic diagram below simply explains the integration of the two equally important main variables that will bring about Standard HR Policy acceptable to all the member schools of the DWEA. Institutionalizing human resource policies will help in aligning strategies and decision-making process in order to achieve visions and objectives.

\section{Nadlers' Human Resources Management (HRsM) Classification Model}

Every Manager's Guide to Human Development, a book written by Leonard Nadler and Zeace Nadler (1992), contains HRsM with four (4) areas of concern, namely: Human Resource Management, Human Resource Development, Human Resource Environment, and other Human Resource Areas. Each area has different HR activities. This study will focus on Human Resource Management seven (7) HR activities: Hiring, Training and Development, 


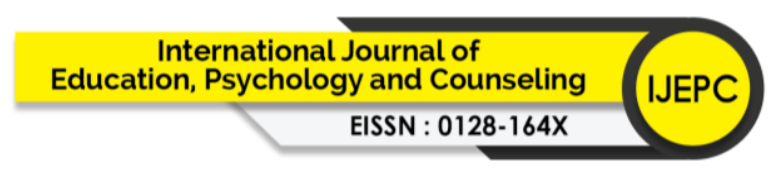

Volume 5 Issue 37 (December 2020) PP. 379-385

DOI 10.35631/IJEPC.5370030

Compensation and Benefits, Employee Relations, Performance Appraisal, Work-Life Balance and Health and Safety.

The Congruence Model was developed in the early 1980s by organizational theorists David A. Nadler and Michael L. Tushman. It is based on the principle that a team or organization can only succeed when the work, the people who do it, the organizational structure, and the culture all "fit" together - or, in other words, when they are "congruent", thus an improved organizational performance (Sabir, 2018).

\section{Research Methodology}

This research reviews existing literature that highlight the relationship between DWEA core values namely: integrity, excellence, evangelization, leadership, commitment, social responsibility and components of organizational culture that are integrated with the HR practices like hiring, training and development, compensation and benefits, employee relations, performance appraisal, work-life balance and health and safety. The journals consisting of local and international studies were synthesized, rationalized, and presented in this paper. The reviewed literature excludes books, book chapters, and conference proceedings.

\section{Conclusion}

Human resource (HR) policies are principles or objectives instituted by the management to preempt misunderstanding between the employer and employee about their rights and obligations to the organization (Lakshmi \& Matsa, 2020). They support the organization's vision, mission and culture that should be properly communicated to the employees for better understanding to avoid infractions (Berman, 2016).

Over and beyond these human resource policies is also the aspect of its accountability to the betterment of the person in performing his duties and responsibilities as a worker. HR Policies together with its procedures and programs are key support for the fulfilment of the organization's vision, mission and goals (Berman, 2016). The organization hires employees from different backgrounds thus, policies should respond to their diverse cultures as well (Khushk, 2019).

With this research, several concepts are taken into considerations in making sure that the SVD has performed such accountability and responsibility towards its clientele in particular, and the community in general. It also hopes to describe and generalize a specific organizational culture that can be truly adapted by the members of these academic communities in the context of a highly plausible and valued work environment guided by the SVD Vision, Mission, and Goals.

\section{References}

Alfante, F. \& Aguiling H., (2015). Towards a Catholic Model HR Program: Integration of Prophetic Dialogue to HR Activities of the Catholic Schools in the Philippines. International Journal of Human Resource and Procurement 4, (5), 14-19.

Asif, M. \& Gouthier, M. (2013). What service excellence can learn from business excellence models. Total Quality Management and Business Excellence, 25(5-6). DOI: 10.1080/14783363.2013.839348

Berman, S., (2016). Why human resources policies and practices are critical to improving the patient experience. Patient Experience Journal, 3(2). 


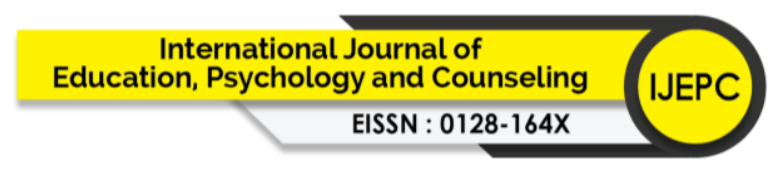

Volume 5 Issue 37 (December 2020) PP. 379-385

DOI 10.35631/IJEPC.5370030

Bulmash, B. (2016). Entrepreneurial Resilience: Locus of Control and Well-being of Entrepreneur. Journal of Entrepreneurship \& Organization Management, 05 (01). DOI: 10.4172/2169-026X.1000171

Carey, W. (2011). Coaching models for leadership development: An integrative review. Journal of Leadership Studies, 5 (1). https://doi.org/10.1002/jls.20204

Hamm, R. (2013). Leading with Integrity: How to live a life that matters. Christian Bible Studies.

Jaeger, A. (2017). Achieving business excellence through self-assessment for personal and professional excellence. Total Quality Management and Business Excellence, 29(3), 121. DOI: $10.1080 / 14783363.2017 .1288564$

Khushk, A. (2019). Impact of HR policies and practices on employee job satisfaction: evidence from Pakistan Telecommunication Ltd (PTCL) Hyderabad. SEISENSE Journal of Management Pakistan, 2(2).

Laforet, S. (2016). Effects of organizational culture on organizational innovation performance in family firms. Journal of Small Business and Enterprise Development, 23(2), 379407.

Lakshmi, M. \& Matsa, P. (2020). A study on impact of HR policies towards employee retention in organization. International Journal of Trend in Scientific Research and Development, 4(3)3, 484-487.

Layugan, M. (2012). The Philippine SVD Schools: An Historical Inquiry into The Beginnings and Evolution of the Engagement of the Society of the Divine Word in Education. The Journal of History, 181-220.

Mujib, H. (2017). Organizational identity: an ambiguous concept in practical terms. Administrative Sciences, 7(28), 1-30.

Nadler, L. \& Nadler, Z., (1992). Every Manager's Guide to Human Resource Development. San Francisco: Jossey-Bass Publishers.

Presmanes, J. (2012). Inculturation as Evangelization: The dialogue of faith and culture in the work of Marcello Azevedo. DOI: 10.2307/41511279

Sabir, A., (2018). The Congruence Management-a Diagnostic Tool to Identify Problem Areas in an Company. Journal of Political Science and International Relations, 1 (2), 3438.

Sarvaiya, H., Arrowsmith, J., \& Eweje, G. (2019). Exploring HRM involvement in CSR: variation of Ulrich's HR roles by organisational context. The International Journal of Human Resource Management, DOI: 10.1080/09585192.2019.1660698

Schein, E. H. \& Schein, P. (2017). Organizational Culture and Leadership. John Wiley \& Sons, Inc., $5^{\text {th }}$ Edition

Shen, J. \& Zhu, C. J. (2011). Effects of socially responsible HRM on employee organizational commitment. The International Journal of Human Resource Management, 22(15), 116. DOI: $10.1080 / 09585192.2011 .599951$

Van Waeyenberg, T., Peccei, R., \& Decramer, A. (2020). Performance management and teacher performance: the role of affective organizational commitment and exhaustion. International Journal of Human Resource Management. https://doi.org/10.1080/09585192.2020.1754881

Zagenczyk, T. J., Purvis, R. L., Cruz, K. S., Thoroughgood, C. N., \& Sawyer, K. B. (2020). Context and social exchange: Perceived ethical climate strengthens the relationships between perceived organizational support and organizational identification and commitment. The International Journal of Human Resource Management. Advance online publication. https://doi.org/10.1080/09585192.2019.1706618 